\title{
Do Czech Companies Disclose Revenue in Accordance with IFRS Requirements?
}

\author{
Katerina Knorová
}

\begin{abstract}
:
Revenue is one of the key indicators informing users of financial statements about company's performance. The different approaches to revenue recognition are analysed in the first part of this paper. The second part addresses the convergence of US GAAP and IFRS in the area of revenue recognition and examines the new converged revenue standard IFRS 15 . The third part focuses on the IFRS disclosure requirements set by the current standard IAS 18 and compare to the new ones defined by IFRS 15 . The empirical study analyses consolidated financial statements of Czech listed companies and assesses the compliance with current revenue disclosure IFRS requirements.
\end{abstract}

Key words: Revenue recognition; Revenue disclosure; IAS 18; IFRS 15.

JEL classification: M41.

\section{Introduction}

Revenue is considered to be one of the most important indicators for investors and other users of financial reports. Therefore, the revenue recognition approaches, revenue definition and disclosed information could impact their decisions significantly. Accordingly, the first part of the paper focuses on the analysis of general approaches to revenue recognition and comparison of revenue definitions according to different accounting views.

Consequently, this paper addresses the question of convergence of the two main worldwide systems of financial reporting, US GAAP and IFRS, in the area of revenue recognition.

Finally, the primary aim of the empirical part of the paper is to review the disclosure requirements set by current revenue standard IAS 18 and compare with the new revenue guidance IFRS 15 and to assess whether Czech companies report revenues in compliance with these requirements.

Kateřina Knorová; University of Economics in Prague, Faculty of Finance and Accounting, Department of Management Accounting, Winston Churchill Square 4, 13067 Prague 3, Czech Republic, <katerina.knorova@vse.cz>.

The article has been prepared under institutional support VSE IP100040. 


\section{Relevance of revenue in decision making and performance reporting}

According to the IASB Framework, the primary objective of financial statements is to provide decision-useful information to a wide range of users. Revenue is certainly one of the most important and useful indicators in informing capital providers, as it is (Wagenhofer, 2014):

- Important measure of company's financial performance.

- Source of profitability and value generation of a company in a particular period.

- Measure of the size of the company.

- Common measure of growth expressed as a change in revenues over period.

- Used for calculating the value of the firm.

Revenue is particularly important in investment decision (Wustemann, Kierzek, 2005). Based on the trends and the growth of revenue investors and analysts evaluate the firm's past performance and predict also the capacity to generate future revenue and cash flow. There are some advantages to apply revenues rather than earnings because (Wagenhofer, 2014):

- Revenues are more homogenous and persistent than expenses and, consequently earnings.

- Changes in performance are reflected in revenues more directly than in expenses, many changes in costs can be delayed.

- Revenues can be used to value a firm with a history of losses.

Revenues are not only used by external users of financial reports for their analysis and decisions but furthermore they serve as the key performance indicator for internal users (management). Revenues are sometimes applied in setting performance targets and to define management incentives and compensation. Nevertheless, more often revenue is not a primary measure but serves as a secondary measure of performance because it impacts earnings and earnings-based measures. Principles of revenue recognition therefore affect the timing of earnings; it means they also determine profits recognition.

\subsection{Revenue recognition}

The question of when revenue should be recognized is therefore one of the key question of accounting theory and the crucial issue for determining financial performance. Recently this issue has gained further attention (Wagenhofer, 2014), mainly because new business models with specific and complex contracts with customers were adopted and more complex transactions emerged.

Generating of revenues is connected with earnings cycle which includes several risks: technical, product, input price, sales quantity and price, credit risk and risk 
of possible obligations after delivery. "Revenue recognition determines which transactions must have been completed and which risks must be resolved before revenue is recognized. Revenue recognition contains two interrelated decisions: One is when to recognize or start to recognize revenue, the other is how much revenue to recognize, which is a measurement issue." (Wagenhofer, 2014, p. 350 and p.359). Early recognition leads to high uncertainty of the amount of revenue recognized, late recognition implies highly certain amount of revenue but less timely information. There is often a trade-off between relevance and reliability as well as timeliness and precision of the accounting information.

\subsection{Revenue definition}

In general, there are two distinct major accounting approaches to the definition and recognition of financial statements elements - the revenue and expense approach and the asset and liability approach. These two different accounting views regarded as two competing accounting models might possibly in some cases lead to a different accounting treatment in identical circumstances (Wustemann, Kierzek, 2005). The different accounting approach arises from the distinct principal objectives of financial statements.

The main objective of financial statements under the revenue and expense view is to measure the firm's performance defined as its efficiency and changes of the efficiency in the course of time - in comparison to previous periods. Revenue recognition according to the revenue and expense view complies with the three core principles:

- Realization principle - revenue is recognized when goods or services are exchanged for cash or claims to cash.

- Matching principle - costs are matched with the associated revenues.

- Accrual principle - transactions are recognized in the period in which they occur not in the period when the corresponding cash flow arises.

To the contrary, the principal aim of financial statements according to the asset and liability view is to provide information of the firm's financial position interpreted as the firm's wealth (Wustemann, Kierzek, 2005).

While under the revenue and expense approach the profit is measured by the excess of revenues over the expenses, the asset and liability approach defines the profit as the increase in the entity's wealth. Accordingly, in compliance with the asset and liability approach revenues and expenses are indirectly defined as changes in assets and liabilities. Therefore, the revenue and expense definition is generally broader by the asset and liability view and might incorporate elements, such as gains from the revaluation of assets and liabilities which are not included in profit under the revenue and expense view. 
According to Wustemann and Kierzek (2005), IASB Framework and IFRS accounting standards encompass elements of both approaches - the revenue and expense as well as the asset and liability and argue that IFRS cannot be classified as a consistent accounting system because it includes components of the two partially conflicting views. They conclude that because of sometimes contradictory accounting treatment a clear objective of IFRS financial statements cannot be identified.

The critical point that incomes and expenses are not correctly defined in the IASB Framework raised also Barker (2010). The main argument is that incorrect definitions of income and expenses mainly due to inconsistency with the doubleentry logic lead to flawed formulation of profit in IFRS (Barker, 2010). While income and expenses are explicitly defined, the profit is not. The IASB Framework adopts the asset and liability view in defining the key elements of financial statements - assets, liabilities, equity, income and expenses. The core definition is the one of assets; the other element's definitions follow from the definition of assets. Income and expenses are correspondingly defined as increases and decreases in net assets (other than from transactions with equity holders). Barker (2010) suggests that income and expenses should be rather defined as changes in equity.

Nobes (2012) picks up the threads of Barker's conclusions and extends the discussion to the definition of revenue. He notes that revenue is not correctly defined in IAS 18 neither in the new revenue IASB/FASB exposure draft. The Framework distinguishes two types of income: revenue and gains but does not formally define them. Revenue is said to arise in the course of ordinary activities. Gains are defined residually as income other than revenue. The principal objection of Nobes is the definition of ordinary activities, which is not clear, and so subsequently the distinction of revenues and gains can be misleading (Nobes, 2012).

By the opinion of Wagenhofer (2014), even though the two different accounting approaches - the revenue and expense approach and the asset and liability approach - define performance differently and presume the primacy of different elements of financial statements, they can be designed to result in similar outcomes.

Wagenhofer (2014) concurrently pursues the question whether the "transfer of control" criterion included in the new IFRS 15 is consistently applied within the whole standard. He remarks that after appending additional conditions of revenue recognition in the revised exposure draft, the new standard essentially recovers the percentage of completion method of current IAS 11 and therefore enables revenue recognition not fully consistent with the core "transfer of control" principle 
(Wagenhofer, 2014). He also mentions other specific rules incorporated in the new standard that are not fully internally consistent, for example input-based methods of measurement of complete performance obligation that is satisfied over time and rules for licenses of intellectual property. Finally, he comes to the conclusion that while some specific rules added into the new standard could be regarded as undesirably inconsistent they follow the basic revenue recognition requirement that revenue should be recognized when the most important risk in the earnings cycle is resolved. As the risks of customer products and services differ widely, the different recognition criteria are in accordance with the main requirement of risks resolution.

\section{Convergence of US GAAP and IFRS in the area of revenue recognition}

The globalization, the movement of world economies and the growth of crossborder investing and capital flows accelerated the need for a unified set of global accounting standards (Fosbre, Kraft, Fosbre, 2009). Since the beginning of 21st century FASB and IASB committed to reach convergence between IFRS and US GAAP accounting standards. In 2001 IASB was charged by the main authorities of the world's capital markets to develop a single set of accounting standards and to spread IFRS worldwide (Bohusova, Nerudova, 2015). In 2007 the SEC allowed foreign companies on US stock exchanges to use IFRS standards for financial reporting without reconciliation to US GAAP. Finally, this step created a strong mandate to converge US and international accounting standards.

Current US GAAP and IFRS differ mostly in the area or general approach. IFRS accentuates its focus towards a principle-based accounting and also stresses the importance of management's and auditor's professional judgement to assure that financial statements faithfully reflect the economic substance of transactions. US GAAP are based primarily on rules with specific application guidance.

One of the main driving forces that speeds up the process of creation and adoption of unified accounting standards globally is the revenue recognition (Fosbre, Kraft, Fosbre, 2009). Firstly, due to not consistent accounting rules in the area of revenue recognition: current guidance comprises more than a hundred standards in US GAAP and two standards in IFRS, some of US GAAP standards are industry specific with possible conflicting rules and also principles of both IFRS standards are not fully consistent and easy applicable beyond simple transactions. Secondly, there are differences in revenue recognition principles: according to IFRS revenue is generally recognized when a sale occurs while under US GAAP revenue recognition is commonly deferred until earnings process has occurred and expenses are recorded and are matched against the earned revenue. Thus companies using IFRS report higher revenues compared to corporations following 
US GAAP. As mentioned before, revenues are regarded by investors as a measure of net worth, so the firms with higher reported revenues will have an advantage.

The initiative to issue a joint revenue standard was also driven by the fact that current standards - the US and IAS 11 and IAS 18 do not address changing business models and do not provide clear guidance to specific business situations. Over the past years, US standards reacted to business changes and complex business situation by issuing particular standards for different industries and business models, which inevitably give in some cases conflicting guidance for similar transactions. The IAS principle based revenue standards - IAS 11 and IAS 18 - were created in the early 1990's. Yet, these standards do not respond to new business models therefore the application to more complex business transactions could be difficult (Wagenhofer, 2014).

Apart from this goal the main objective of the joint project was to eliminate inconsistencies within current IFRS revenue recognition principles and between revenue recognition criteria and the definition of assets and liabilities in the IASB Framework (Wustemann, Kierzek, 2005).

\subsection{IFRS 15 - the new revenue recognition standard}

In May 2014, the IASB and the FASB jointly issued a new revenue recognition standard, Revenue from Contracts with Customers. The effective date of IFRS 15 originally fixed on 1 January 2017 was postponed by one year to 1 January 2018.

The new standard is a result of a joint project of the IASB and the FASB which took more than 6 years of meetings, deliberations and drafts. The first joint discussion paper was issued in 2008; followed by a joint exposure draft in 2010 . After this publication, boards received nearly 1000 comment letters. Many of the suggestions and comments were incorporated and in 2011 a revised exposure draft was published.

As mentioned before, the main objective of IFRS 15 is to create a single, joint revenue standard for various industries and capital markets and adopt to new business models with often highly complex contracts and provide guidance for revenue recognition under this complex business situations and conditions. The new standard will replace nearly all existing revenue guidance both under IFRS and US GAAP.

IFRS 15 is considered to be the most significant improvement in global financial reporting. According to IASB and FASB the new standards creates a single model based on clear principles as well as a robust and comprehensive framework for addressing revenue issues. Its goal is to remove inconsistencies and weaknesses in previous revenue requirements, improve comparability across industries and 
markets and provide more useful information to users of financial statements through improved disclosure requirements (IFRS 15, 2014).

According to the new standard, a contract with a customer is considered as a necessary precondition of revenue recognition (Wagenhofer, 2014). Revenue should be recognized when the promised goods or services are transferred to the customer, i.e. when company satisfies performance obligation from the contract. This transfer is defined as "when the customer obtains control of that asset" (IFRS 15, para 31). Control is specified as the ability to direct the use of the asset, to obtain benefits from the assets and to prevent others from doing so (IFRS 15, para $33)$.

\section{IFRS disclosure revenue requirements}

In accordance with the currently effective revenue standard - IAS 18 a company shall disclose (IAS 18, 1993):

- The accounting policies adopted for the recognition of revenue, including the methods adopted to determine the stage of completion of transactions involving the rendering of services;

- The amount of each significant category of revenue recognized during the period, including revenue arising from: sale of goods, rendering of services, interest, royalties, dividends; and

- The amount of revenue arising from exchange of goods or services included in each significant category of revenue.

The current revenue disclosure requirements are considered to be insufficient. Therefore, the improvement of disclosure requirements was one of the main objectives of the new standard. During the new revenue standard preparation there was a lot of discussion among the users and the preparers of financial statements which resulted into the refinement of disclosure requirements in IFRS 15. The overall volume of disclosure has increased and according to IASB and FASB new requirements represent a significant improvement from the previous ones (IFRS 15, Basis for conclusions, 2014). The enhanced disclosure requirements should provide more useful and comprehensive revenue information.

The new standard IFRS 15 defines the objective of disclosure requirements which is to disclose sufficient information to enable users of financial statements to understand the nature, amount, timing and uncertainty of revenue and cash flows arising from contracts with customers. To achieve that objective an entity shall disclose qualitative and quantitative information about all of the following (IRFS 15, 2014): 
- Its contracts with customers - revenue recognized from contracts with customers separately from other sources of revenue;

- The significant judgements and changes in the judgements, made in applying this Standard to those contracts; and

- Any assets recognized from the incremental costs to obtain or fulfil a contract with a customer.

The standard IFRS 15 also specifies a requirement that the entity shall consider the level of detail necessary to satisfy the disclosure objective and how much emphasis to place on each of the various requirements. It does not state explicitly the level of aggregation of disclosed information, on the contrary it demands useful information to be disclosed, meaning that the entity shall not obscure the usefulness by either the inclusion of a large amount of insignificant detail or by aggregation of items with substantially different characteristics.

\section{Empirical study}

The empirical study provides a review of revenue disclosure of Czech companies. The aim of the study is to evaluate the consistency and accordance with IFRS requirements in financial statements and to assess the quality of disclosed information as well.

\subsection{Methodology}

Only data from statements of comprehensive income (resp. income statements) and from notes to financial statements were considered, other publicly published information (ex. annual reports) were not included in this analysis. The last accounting period available i.e. the fiscal year 2014 is a subject of this survey. As mentioned before, the new revenue standard IFRS 15 was issued during 2014 and will be effective from 2018 onwards. Thus, the empirical study addresses the compliance of revenue disclosure with current revenue guidance in force, i.e. IAS 18.

From 2005 onward, publicly traded companies in the EU are obliged to apply IFRS in their consolidated accounts. In accordance with the EU requirement, the Czech accounting law implies the obligation for listed companies to apply IFRS in their financial statements (Czech accounting law, para 19a) and the number of Czech companies reporting under IFRS is growing (Mejzlík, Arltová, Procházka, Vítek, 2015). For the purpose of this analysis, consolidated financial statements of Czech listed companies were analysed. 


\subsection{Sample selection}

Czech National Bank registered 64 listed companies on the Prague Stock Exchange at the end of 2014, 19 of them were foreign companies which were excluded from this research study. Afterwards 15 financial institutions (banks, investor funds and insurance companies) and 2 municipalities were removed as well because it was decided to study non-financial firms only in order to obtain comparable data. Finally, based on preliminary analysis of financial statements, another 9 companies were excluded from the analysis for the same reason -6 leasing companies and 3 companies which went bankrupt or reported no revenues. Thus, 19 companies were chosen and their officially published consolidated financial statements at the Registration Office (justice.cz) are the subject of this study (see Tab. 1).

\section{Tab. 1: Czech listed companies used for analysis of revenue disclosure} requirements according to IFRS

\begin{tabular}{llr}
\hline Company & $\begin{array}{l}\text { Industry } \\
\text { Sector * }\end{array}$ & $\begin{array}{r}\text { Revenues in mil. } \\
\text { CZK }\end{array}$ \\
\hline ABS Jets, a. s. & H & 1,345 \\
BigBoard Praha, a. s. & M & 897 \\
České dráhy, a. s. & H & 33,036 \\
ČEZ, a. s. & D & 200,657 \\
Dalkia Česká republika, a. s. & D & 10,803 \\
ENERGOAQUA, a. s. & D & 659 \\
ENERGOCHEMICA SE & G & 5,046 \\
E4U, a. s. & M & 69 \\
KAROSERIA, a. s. & G & 227 \\
LEO Express, a. s. & H & 178 \\
O2 Czech Republic, a. s. & J & 44,689 \\
Philip Morris ČR, a. s. & G & 14,049 \\
Pivovary Lobkowicz Group, a. s. & G & 1,202 \\
Pražské služby, a. s. & E & 2,781 \\
Severomoravské vodovody a kanalizace Ostrava, a. s. & E & 2,217 \\
TESLA KARLÍN, a. s. & C & 117 \\
TOMA, a. s. & M & 503 \\
\hline
\end{tabular}




\begin{tabular}{llr}
\hline Company & $\begin{array}{l}\text { Industry } \\
\text { Sector * }\end{array}$ & $\begin{array}{r}\text { Revenues in mil. } \\
\text { CZK }\end{array}$ \\
\hline UNIPETROL, a. s. & G & 124,229 \\
ZONER software, a. s. & G & 124 \\
\hline
\end{tabular}

Source: financial statements of selected companies, year 2014.

Note: *industry NACE classification: C - Manufacturing; D - Electricity, gas, steam and air conditioning supply; E - Water supply, waste disposal and redevelopment; F Construction; $\mathrm{G}$ - Wholesale and retail trade, repair of motor vehicles and motor-cycles; $\mathrm{H}$ - Transport a warehousing; J - Information and communication; M - Professional, scientific and technical activities.

Quantitative content analysis of revenue disclosure in statements of comprehensive income (resp. income statements) of above mentioned companies was applied and furthermore, qualitative analysis of disclosed revenue information in notes to financial statements was provided in order to consider the compliance with IFRS disclosure requirements.

\subsection{Content analysis of statements of comprehensive income}

Using the content analysis of 19 statements of comprehensive income (income statements), three characteristics describing the level of disclosed information were identified:

- Classification of expenses recognized in profit or loss, i.e. whether the company uses "nature of expense" method or "function of expense" method. The latter one is by IASB considered as the method that provide more relevant information to users.

- Form of statement of comprehensive income, i.e. whether the company presents all items of income and expense in a single statement of comprehensive income or in two statements: in a separate income statement and a second statement showing components of other comprehensive income. Both forms are considered as equal, hence this characteristic is just informative.

- Level of detail of disclosed revenue in the statement, i.e. whether the company reports only total aggregated revenue as one amount or whether there is a detailed structure of revenues presented directly in profit and loss statement.

The result of content analysis of statements of comprehensive income is presented in Tab. 2: 


\section{Tab. 2: Characteristics of statements of comprehensive income}

\section{Characteristics}

$\mathrm{N}$ of comp.

$\%$

Classification of expenses

nature of expense

function of expense

Statement of comprehensive income

single statement of comprehensive income

Detail of revenue in the statement

only total revenue amount

detailed information by categories

Source: statements of comprehensive income of selected companies, year 2014, authorial computation.

The analysis proved differences of presented information in statements of comprehensive income among selected companies. It's evident that companies are reluctant to disclose detailed revenue information directly in financial statements. Only one firm of all provide more detailed revenue split in the statement of comprehensive income, the others follow the aggregated classification of revenue and expenses. Concurrently, the minority of companies $(21 \%)$ uses "function of expense" classification, the majority (79\%) applies "function of expense" method that provides less relevant information.

\subsection{Content analysis of notes to financial statements}

Disclosed revenue information in notes to financial statements was evaluated and two, resp. three main features of the quality and the level of revenue information recognized:

- Additional revenue detail provided, i.e. whether the company discloses detailed amount of revenue by specified categories, for example by products, geographical regions or by activities. As a majority of companies releases results by operating segments, including revenues by segments, the segment reporting was added into analysis as a separate attribute for evaluation.

- Quality of disclosed accounting revenue policies, i.e. to what extend revenue recognition policies are described, whether the company reveals the measurement policy as well, whether it provides characteristics of the main revenue categories and so on. 
The result of qualitative analysis of notes to financial statements can be found in Tab. 3. The quality of additional revenue detail and disclosed accounting policies were graded on the scale 1-5, considering 1 as the best and 5 as the worst. Detailed explanation of each grade can be found below Tab. 3 .

\section{Tab. 3: Quality of revenue disclosure in notes to financial statements}

\section{Characteristics}

$\mathrm{N}$ of comp.

$\%$

Operating Segments Reporting

Yes

12

$63 \%$

No

4

$21 \%$

Not mentioned

3

$16 \%$

Additional revenue detail

1 - very good

$37 \%$

2 - good $26 \%$

3 - sufficient $32 \%$

4 - some deficiencies $5 \%$

5 - insufficient $0 \%$

Revenue recognition policies

1 - very good $37 \%$

2 - good $47 \%$

3 - sufficient $11 \%$

4 - some deficiencies $5 \%$

5 - insufficient $0 \%$

Source: notes to financial statements of selected companies, year 2014, authorial computation.

Note: Grades explanation - quality of information disclosed scale:

Additional revenue detail: 1- detailed classification of revenue from multiple point of view; 2 - more than one classification view; 3 - detailed information available, only one classification provided; 4 - not specific details provided, only categories required by IAS 18; 5 - none detail provided.

Revenue recognition policies: 1 - definition of revenue, measurement and specific revenue categories definition, concrete information provided; 2 - general definition of revenue and measurement according to IAS 18; 3 - some missing information - measurement or definition of revenue; 4 - insufficient definition, too vague; 5 - no definition of accounting policies. 
The analysis of notes to financial statements showed that the majority of analysed companies disclosed satisfactory details of revenue categories as well as description of accounting policies. Nevertheless, it emerged that there were significant differences of disclosed revenue information among selected companies. On one hand, all companies disclose revenue information within the bounds of current IFRS requirements (none was classified by grade 5), on the other hand the quality and the extent of revenue disclosure differ widely. As it turned out the most important distinctions could be found in the area of additional revenue detail provided in notes to financial statements. While $63 \%$ of companies disclose additional revenue detail from more than one point of view, the rest $37 \%$ of companies provide only one classification or even none additional detailed structure of revenues besides the categories required by IAS 18 .

\subsection{Aggregate comparison of disclosed revenue information by selected companies}

To sum up, all of selected companies disclose revenue information in accordance with current IFRS requirements. Nevertheless, as mentioned above, IAS 18 requirements are considered to be insufficient and need improvement. Both content analysis revealed distinct quality of revenue disclosure among selected companies.

In order to compare the overall quality of revenue disclosures by selected companies, each company was evaluated in terms of compliance with above mentioned criteria. Each company was awarded with set points expressing the quality of disclosed information: 10 points for detailed information in the statement of comprehensive income, 10 points for information about segments reporting (either yes or no), 0-40 points for additional revenue detail and 0-40 points for disclosed revenue accounting policies. The aggregate rating of selected companies can be found in Fig. 1: 


\section{Fig. 1: Quality of revenue disclosure by selected companies}

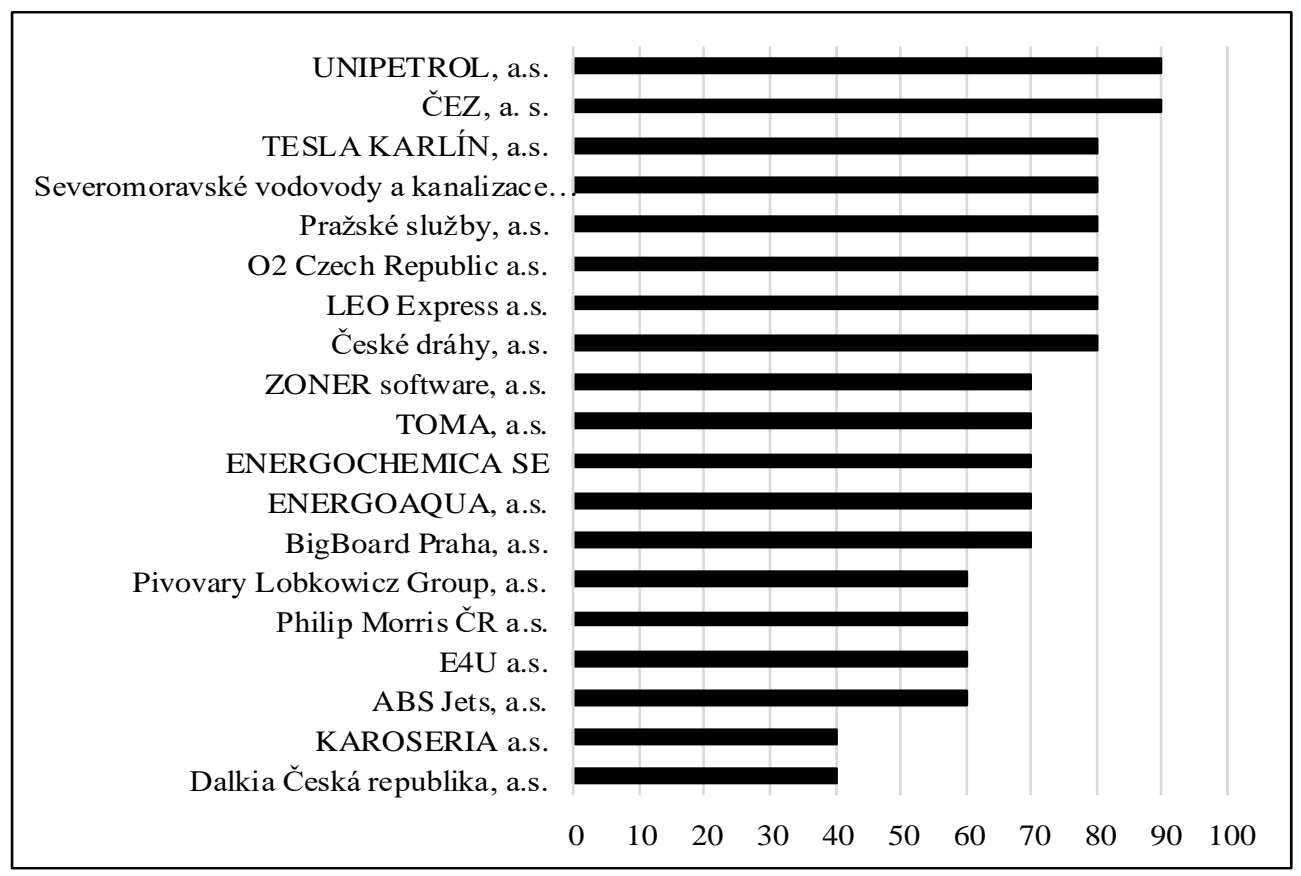

Source: financial statements of selected companies, year 2014, authorial computation.

\section{Conclusion}

The main aim of this paper was to examine whether Czech companies disclose revenue in accordance with IFRS requirements. The content analysis of published financial statements proved that companies complied with current revenue disclosure requirements. Concurrently, it revealed significant differences in the quality of disclosed revenue information beyond the mandatory obligations set by current standard IAS 18. Principal distinctions among selected companies consist in the detailed structure of revenue disclosed on the one hand and the extensiveness of disclosed accounting revenue policies on the other.

Main deficiencies were too vague definitions of accounting policies. Even though the requirement to disclose accounting revenue policies is defined very generally in the standard, it would be useful for users of financial statements to obtain more concrete information about revenue recognition methodology applied mainly in cases of complex transactions and in situations when various categories of firm's revenues differ significantly. 
The other main difference of disclosure is the level and the extent of detailed revenue amounts reported. Some companies disclose only obligatory details according to IAS 18 defined revenue categories, however the majority of companies added at least one facultative classification of revenues.

This study is limited to Czech companies and takes into consideration just one accounting period. Future research could be extended to other European countries and changes in published information over time which is beyond the scope of this analysis.

Simultaneously, as this study was conducted before the application of the new revenue standard IFRS 15, it would be interesting to examine whether the revenue disclosure would change after IFRS 15 becomes effective. Since the new standard does not impose explicitly how detailed information should be disclosed, it rather states the overall principle that company should disclose useful and relevant detail of revenues. The standard setters, the IASB and the FASB, presume that the new standard would improve revenue disclosure and it was at the same time one of the principal aims of the converged revenue project. Future research on this topic is needed to verify these assumptions.

\section{References}

Barker, R., 2010. On the definitions of income, expenses and profit in IFRS. Accounting in Europe 2, 147-158. DOI: 10.1080/17449480.2010.511892.

Bohusova, H., Nerudova, D., 2015. US GAAP and IFRS convergence in the area of revenue recognition. Economics and Management 14, 12-19.

Fosbre, A. B., Kraft, E. M., Fosbre, P. B., 2009. The Globalization of Accounting Standards: IFRS vs. US GAAP. Global Journal of Business Research 1, 61-71.

IASB, 2009. International Financial Reporting Standards 2009. International Accounting Standard Board, London.

IASB, 2014. Basis for Conclusions on IFRS 15 Revenue from Contracts with Customers. International Accounting Standard Board, London.IASB, 2014. IFRS 15 Revenue from Contracts with Customers. International Accounting Standard Board, London.

Mejzlík, L., Arltová, M., Procházka, D., Vítek, L., 2015. The Adoption of International Financial Reporting Standards in the Czech Republic and Its Impact on Corporate Taxation. Politická ekonomie 7, 811-832. DOI: 10.18267/ j.polek.1036.

Nobes, C., 2012. On the definitions of income and revenue in IFRS. Accounting in Europe 1, 85-94. DOI: 10.1080/17449480.2012.664395. 
Knorová, K.: Do Czech Companies Disclose Revenue in Accordance with IFRS Requirements?

Wagenhofer, A., 2014. The role of revenue recognition in performance reporting. Accounting and Business Research 4, 349-379. DOI: 10.1080/00014788. 2014.897867.

Wüstemann, J., Kierzek, S., 2005. Revenue recognition under IFRS revisited: conceptual models, current proposals and practical consequences. Accounting in Europe 1, 69-106. DOI: 10.1080/09638180500379111. 